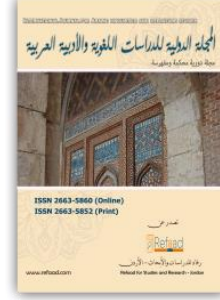

\title{
تجلّيات الوطن في ديوان مملكة اليمام للمتوكل طه
}

\author{
خميس أحمد محمد ريان \\ وزارة التربية والتعليم- رام الله- فلسطين \\ أستاذ مساعد غير متفرغ- جامعة بير زيت- فلسطين \\ khrayyan69@gmail.com
}

يهدف هذا البحث إلى عرض قضايا الوطن التي عبّر عنها الشّاعر في ديوانه؛ لمعرفة إلى أيّ مدى مازال الوطن يشكّل الهمّ

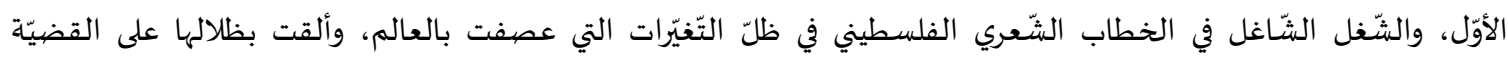
الفلسطينيّة.

واعتمد البحث تلقي النّص الشّعري وتحليله، مفيدًا من المنهج الوصفي التّحليلي الذي يقرأ النّصهوص ويحلّاها، ويفيد

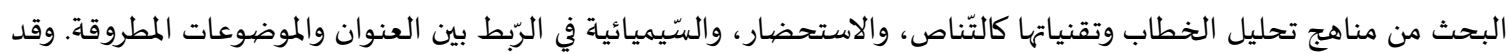

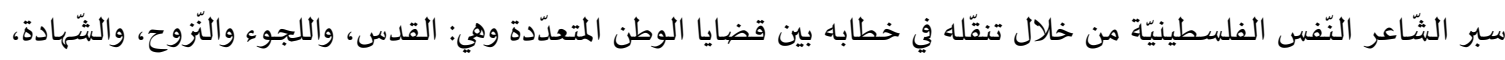

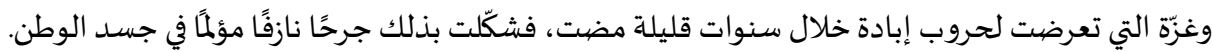

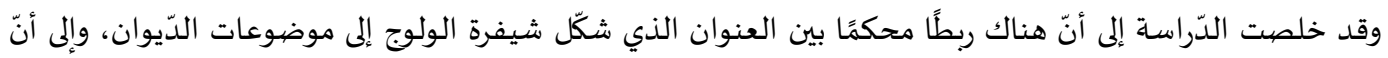

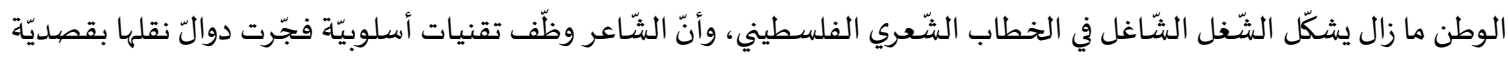
لمتلقيه لدفعها إلى المشاركة الوجدانية، والعمليّة في الذود عن وطناه ومكوّناته.

الكلمات المفتاحية: تجلّيّات الوطن؛ القدس؛ اللجوء؛ الشّهادة؛ التّناص. (9) (1)

منذ أن وطئ المحتل أرض فلسطين، والأدباء الفلسطينيون يقومون بدورهم المنوط بهم، وهو المقاومة بالكلمة جنبًا إلى جنب

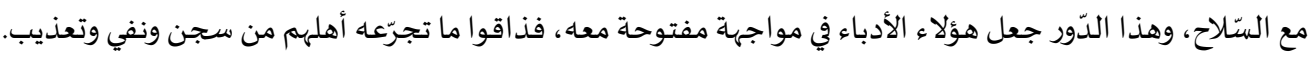

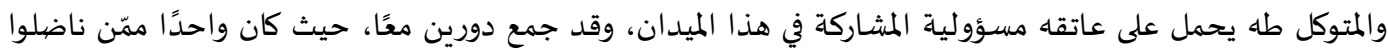

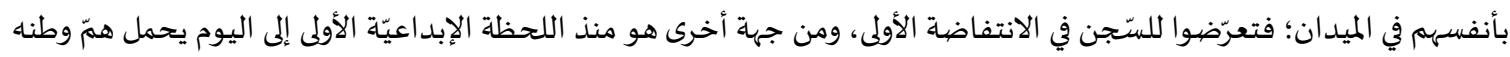

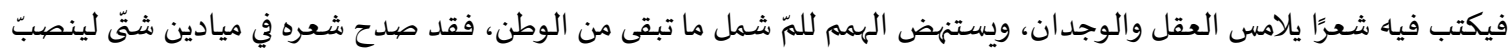

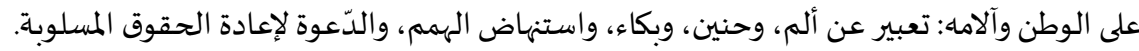

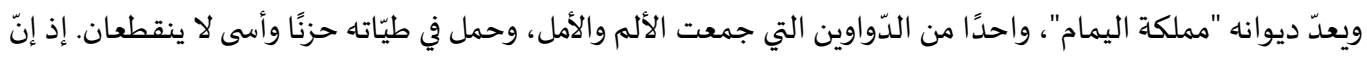

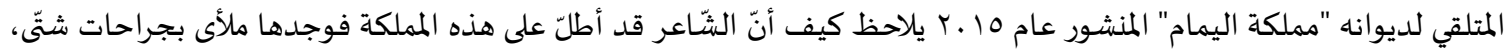

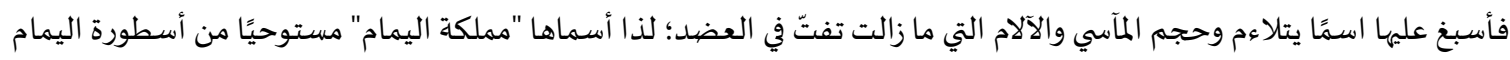
دلالاتها. ويثير عنوان البحث "تجلّيات الوطن في ديوان مملكة اليمام" الذي اختير لقراءة ديوان الثّاعر جملة من التّساؤلات التي تتجلّى من خلال التّدقيق في تحليل القصائد، وعرضهها، وأبرز هذه التّساؤلات:

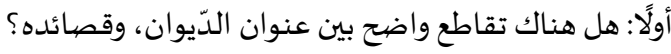

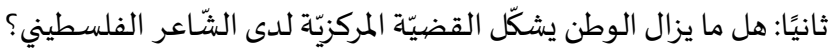

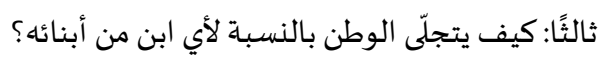


رابعًا: ما القضايا التي شكّلت في مجموعها مملكة اليمام التي اختارها الشّّاعر عنوانا لديوانه؟

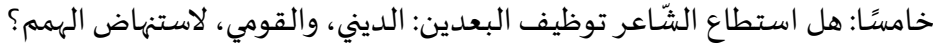

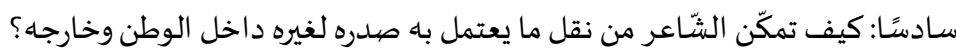

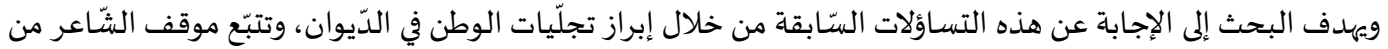

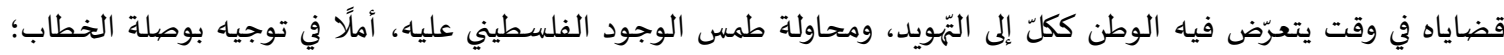
ليتعاضيد الكلّ الفلسطيني في مواجهة المحتل الغاصب، ويستثير همم إخوانه العرب والمسلمين لمؤازرة قضيّتهم المركزيّة. ويعرض البحث الفضاء الموضيوعي، وما يجلّيه من عناصر وتقنيات فنيّة، تنقله من المبدع إلى المتلقي، أملا في التأثير فيهاء،

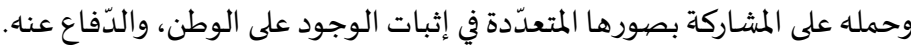
وتشمل القراءة للديوان جملة من القضايا المرتبطة بعنوان البحث، حيث جاءت من خلال تمهيد، وأربعة عناوين: عرض إنساء

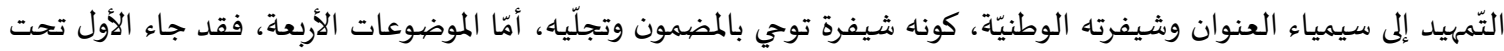

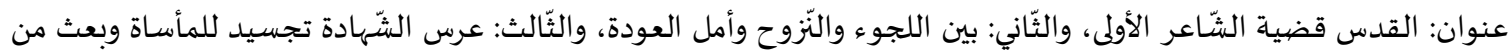

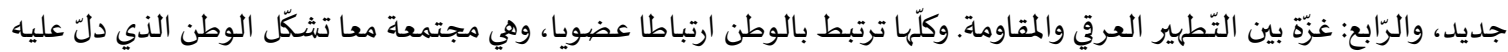
بمملكة اليمام.

ويقوم البحث على تلقّي النّص الشّعري، وتحليله، مفيدا من مناهج الدّراسة النّصية اللسانية في جوانب كالتّناص مثلا،

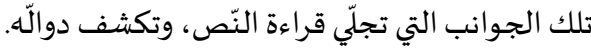

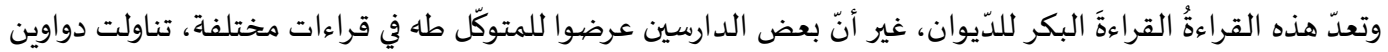
سابقة من مثل قراءة الدّكتور عادل أبو عمشـة الموسومة بـ "دراسة في شعر المتوكل طه" ، حيث وقف على الدّواوين المنشورة قبل عام

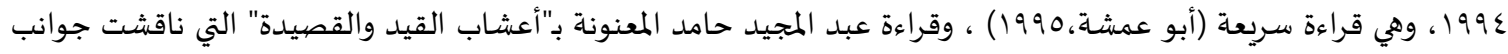

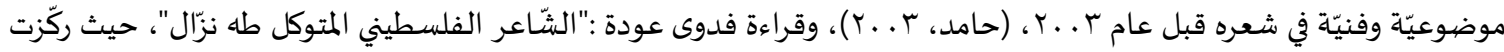

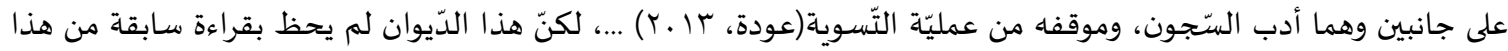

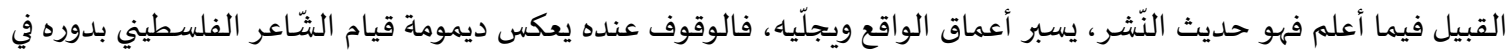

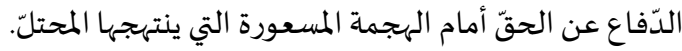

\section{التّمهيد: سيمياء العنوان وشيفرته الوطنيّة}

العنوان هو أوّل ما يقابل المتلقي، وهو يحمل وظائف متعدّدة، أبرزها أربع وظائف وضعهائ جيرار جينيت، وهي الوظيفة

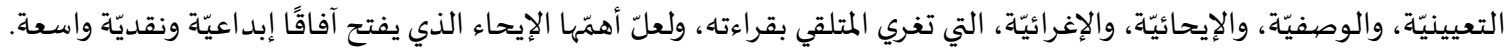

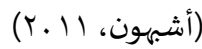

ويمتاز العنوان بعلاقة عضويّة مع النّص الذي يمثله حيث إنّه جزء لا يتجزّاً من القيمة الإبداعيّة المتكاملة للنّص، وبات

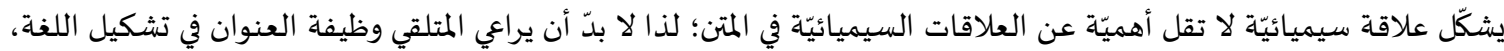

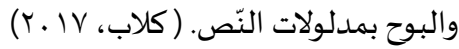
وبالعودة إلى عنوان ديوان الثّاعر" مملكة اليمام"، فقد وفّق الشّّاعر في اختياره؛ ليعبرّ عن مقصده، وهي الكشف عن

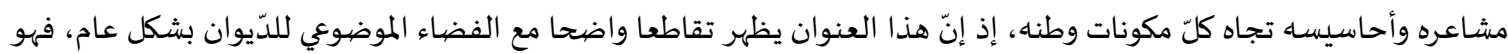
مكوّن من كلمتين هما: (مملكةة) مضافة إلى (اليمام)، حيث تحملان أبعادا دلالية عميقة، فكلمة مملكة تتيح للمتلقي أن يفكّر في عراقة

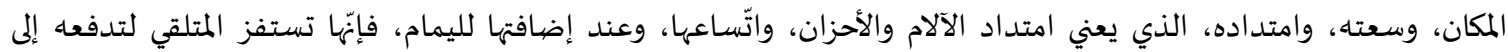

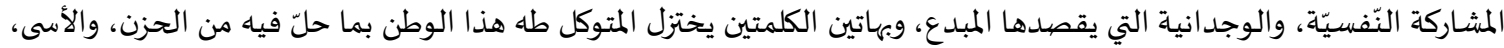

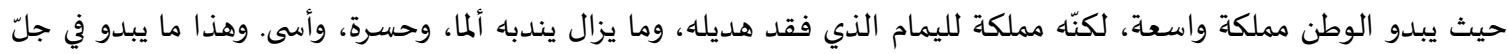
موضهوعات الدّيوان، وهي: قضية القدس التي ما فتئ المسلمون والعرب عامّة، والفلسطينيّون خاصّّة يجعلونها قضيّتهم الأولى، وثمّة

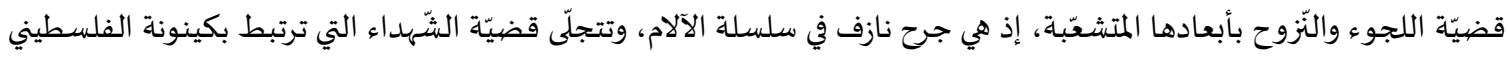
على هذه الأرض، فهؤلاء يرتقون من أجل بقاء الآخرين، بدءًا بمن ارتقى منذ وجود اليهود على هذه الأرض كعبد الرحيم محمود، وانتهاء

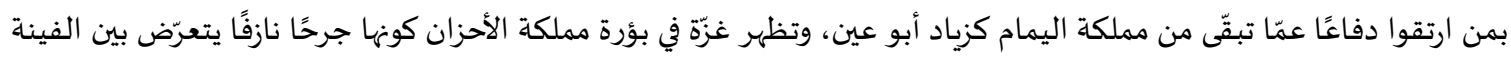
والأخرى إلى حروب أبيد في بعضها عائلات من السّّجلات، وكونها جزءًا رئيسًا من الوطن تنعكس عنس أحزانها على الكلّ الفلسطيني أنّى كان. 
وبهذا يكون العنوان (مملكة اليمام) الشّيفرة الأولى التي تثير في المتلقي مشاعر شتّى من الحزن والألم والأسى؛ لما تحمله

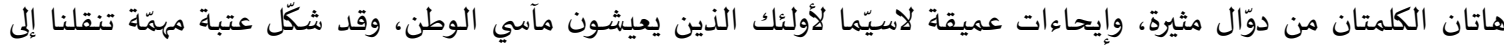

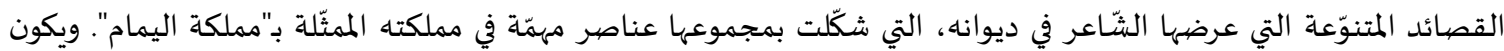

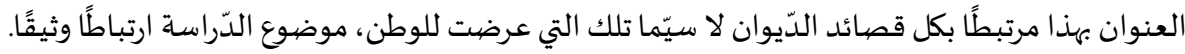

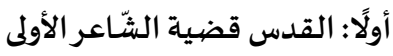

تكتسب القدس أهميّة دينيّة خاصيّة؛ لذا كانت محطٌ أنظار العابرين يحجِّ إلهيا المؤمنون من أصقاع المعمورة، ولهيا أهميّة

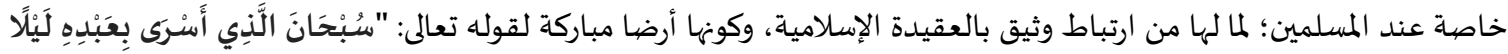

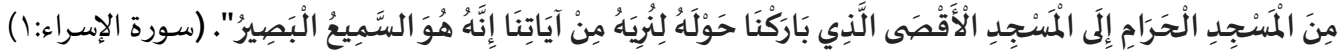

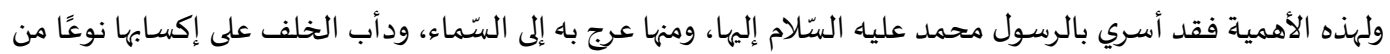

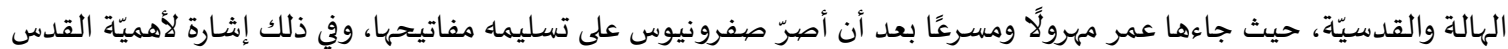
للمسيحيين والمسلمين، وكتب العهدة العمرية التي تحفظ الحقوق لسكانها. (شراب، 1990)

وفي الثَّعر بكاها الثَّعراء كلّما وقعت تحت احتلال، ودعوا إلى تخليصها من براثنه، فهذا العماد الأصفهاني يقول: (عبد المهدي، 1919 )
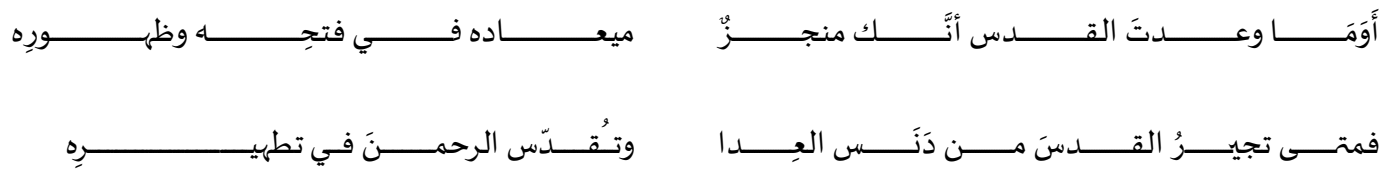

وتغنى الشَعراء بالفتح وتراقصوا طربا على أنغام تحريرها، فالعماد الأصفهاني يقول: (عبد المهدي، 1919)
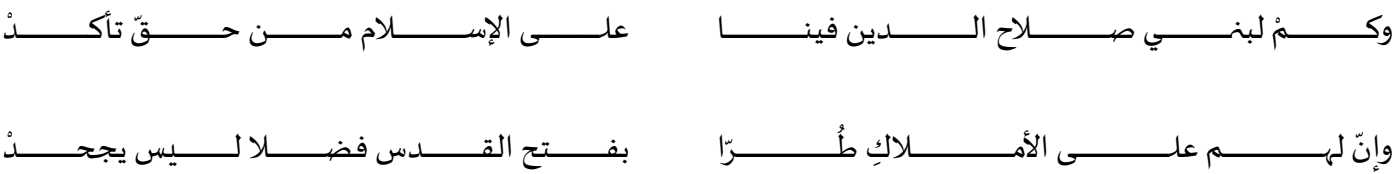

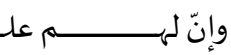

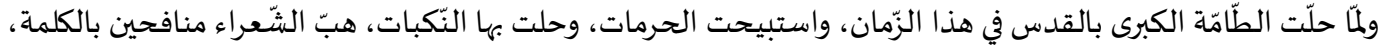

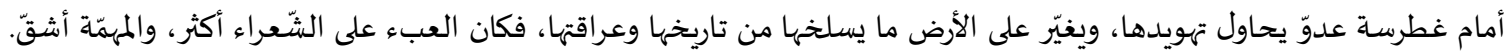

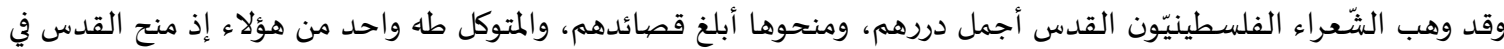

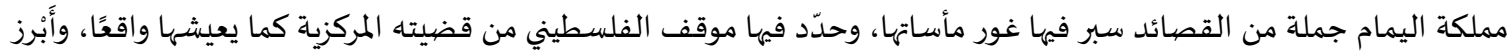

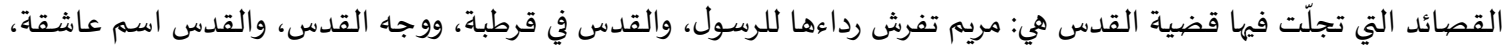

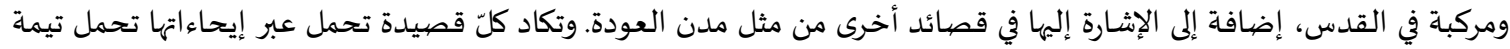
جديدة ترتبط بالقدس، وينقلها المبدع إلى متلقيه؛ ليتفاعل معها.

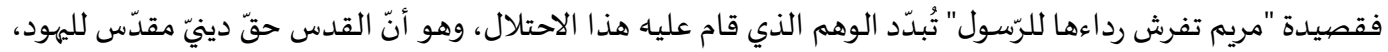

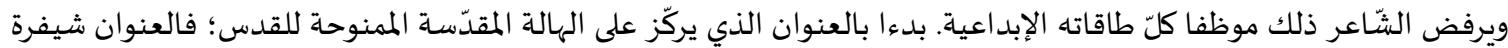

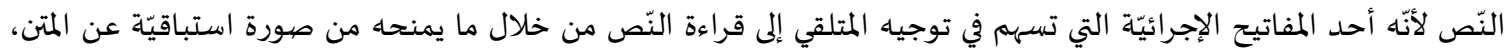

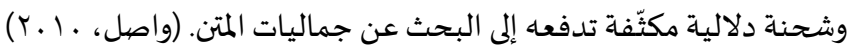

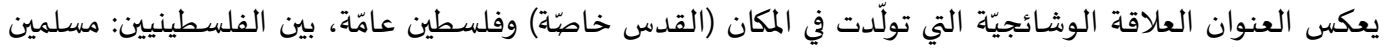

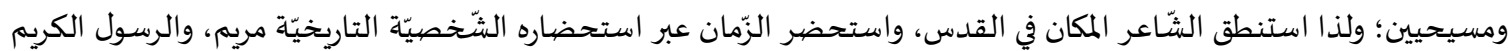

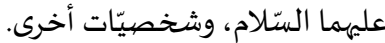

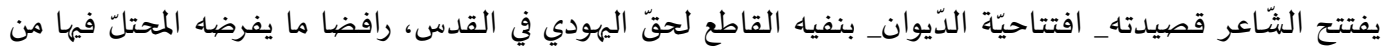

$$
\begin{aligned}
& \text { تغييرات على الأرض لإثبات تاريخ مزيّف لهم على الأرض بقوله: } \\
& \text { لمستّور ظلّ لا يراه الرّا بكبون }
\end{aligned}
$$

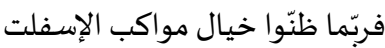




$$
\begin{aligned}
& \text { ما يعطي الشّوارع لونها } \\
& \text { ويهرولون على امتداد سطوحها } \\
& \text { ويعلمون مفارق الطرقات بالوهم الخفيف إتيفاد } \\
& \text { ويكتبون على الحجارة ما يؤكد رحلة الصحراء } \\
& \text { أو أهواء بعض المدّعين } \\
& \text { بأنّ موسى جاء ممتطيا جوادا ... } \\
& \text { كي يسلّم وعده للهاربين }
\end{aligned}
$$

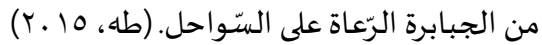

فإذا كان وعد الرّب لموسى في دخول هذه الأرض، فإنّ كل الأنبياء دخلوا القدس، وصيلّوا فيها دون أن يدّعي أتباعهم حقّهم فهها، انظر إليه يقول:

$$
\text { تواثِّ يجيئوا أورسالم }
$$$$
\text { والذي عبر المدينة كان منّا.(طه، } 10 \text {. (Y) }
$$

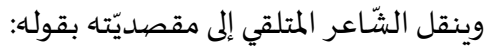$$
\text { ويجيء من رمل الجزيرة }
$$

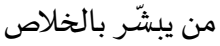$$
\text { ويمنح البشر الطريق إلى الموازين }
$$$$
\text { التي غابت }
$$$$
\text { ويبدأ عهده بعد الة لم يعرفوها }
$$$$
\text { أو يبدل ليلهم بنهارهم }
$$$$
\text { ويقودهم لكرامة هدرت طويلا }
$$

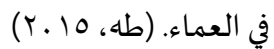

فالقدس إذن بهذا العدل الإلهي تمسي مظلة للجميع تحت حكم إسلاميّ عادل ، لا يُمنع فيها أحد من ممارسة طقوساه، فالكلّ فيها

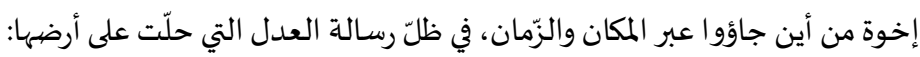
فهينا الأخوّة في المكان أو الزّمان

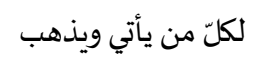

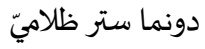

$$
\text { ويبدو خلفه الستّاطور }
$$

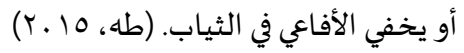

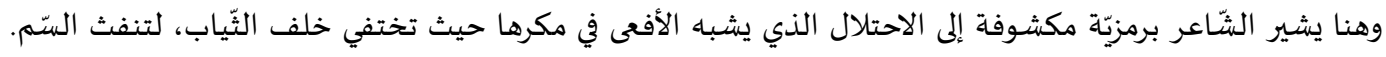

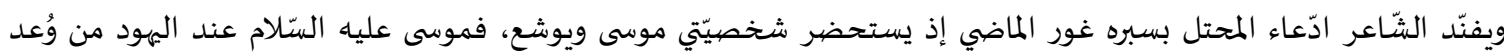

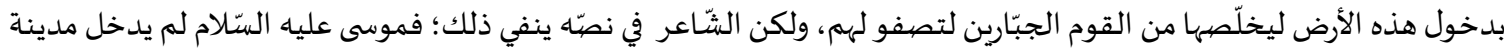

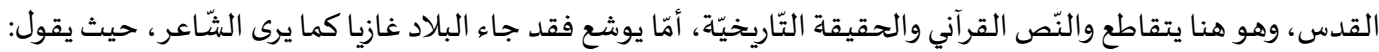

$$
\text { ولم يكن موسى هنا }
$$

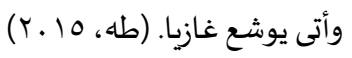

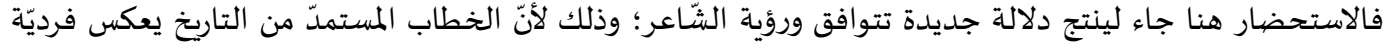

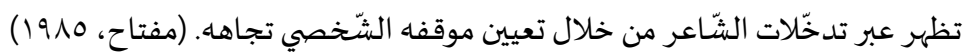

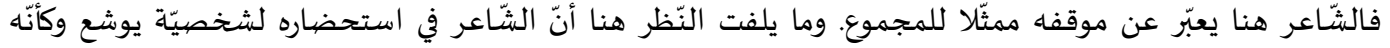

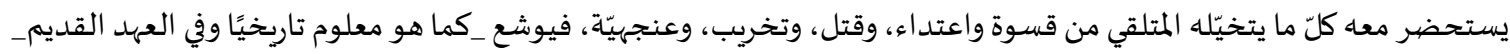
دخل فلسطين بالقوّة وقتل الملوك، فأصبح رمزا للبطش والقوّة، وباستحضاره يكون الشّاعر قد عبّر عن كلّ هذه الدوالّ، حيث ظلّّت 


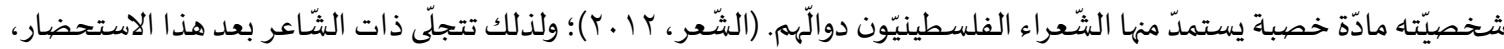
تلك الذّات التي تمثّل الهمّ الجمعيّ الفلسطينيّ، والقوميّ، والدّينيّ. وأنا وريث رسائل الوحي الوحيد فلا جدال ولا نقاش على السّالام على المدينة والسيّلام لها ولي ولمريم العذراء تفرش للرّسول رداءها

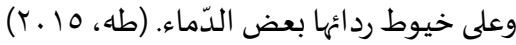

أمّا قصيدة "القدس في قرطبة" فتقوم على المفارقة بين ماضٍ عريق متميّز، وحاضر مؤلم ومزرٍٍ حيث يبدو الشّاعر في هذه

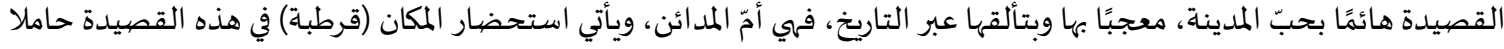

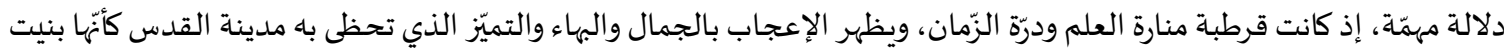

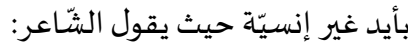

$$
\begin{aligned}
& \text { تقول كأنّ الذي قد أقام المعابد } \\
& \text { والواجهات وأقواسها العاليات } \\
& \text { وأدراجها كسلا للطريق }
\end{aligned}
$$

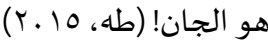

$$
\begin{aligned}
& \text { ولكن كيف أمست قرطبة التي هي القدس الآن؟ } \\
& \text { فكيف ترى وجه قرطبة الآن؟ } \\
& \text { وكيف بآلائها تكذبان؟(طه، } 10 \text { • (Y) }
\end{aligned}
$$

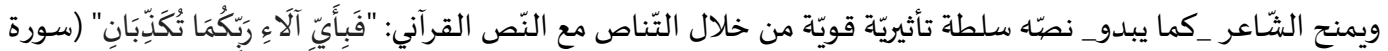

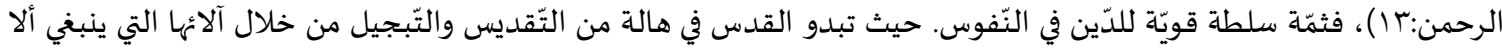

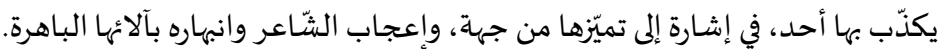

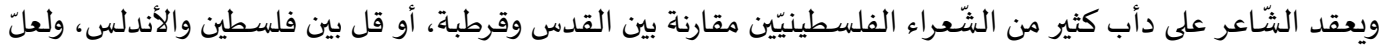

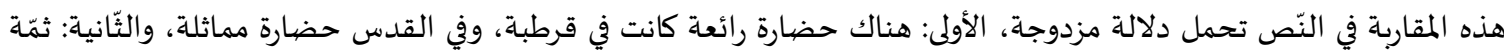

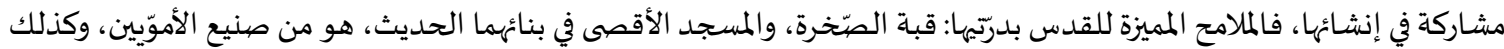

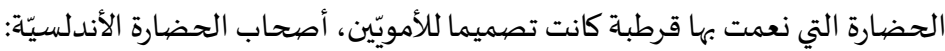

$$
\begin{aligned}
& \text { والنّور أندلس الأمويّ، الذي } \\
& \text { حلّ في ذهب الأقحوان } \\
& \text { وكان ما كان. (طه، } 10 \text {. }
\end{aligned}
$$

ومرّة أخرى ينقلنا الشّّاعر عبر شخصياته إلى الوراء؛ ليبني علاقة جدلية بين ماضٍ مشرق، وحاضر مؤلم، فالشّخصصيات

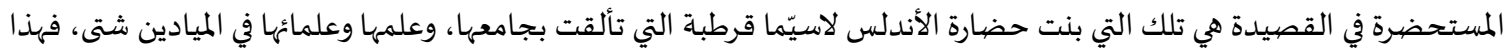
ابن زيدون، وتلك ولادة في أدبهما، وذلك ابن حزم إمام العاشقين بعلماه وعشقـه، وهذا زرياب بفنّه، وذاك ابن فرناس بإبداعه، وغيرهم كثير. ويرى أبو عمشـة أنّ المتوكّل طه استحضر كثيرا من الشّخصيّات الأندلسيّة، إذ كان لها حضيور بارز في دواوينه قبل عام

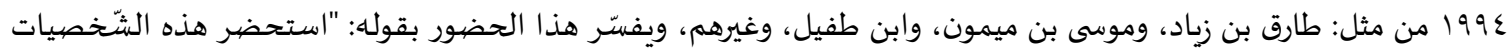
ليبرز من خلالها احتجاجه على مدريد."(أبوعمشـة، 1990) غير أنّ الاستحضيار في هذا الديوان كما أرى حمل إيحاء جديدًا يتساوق مع

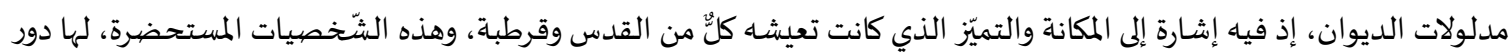

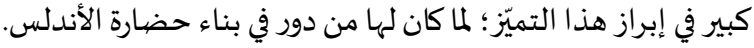

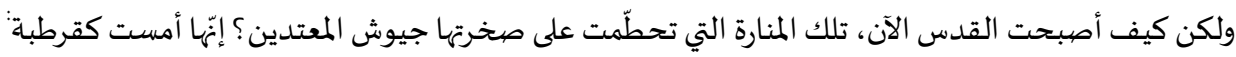




$$
\begin{aligned}
& \text { والقدس مثل قرطبة } \\
& \text { نصف غائبة حاضرة ... } \\
& \text { فكوني يا قرطبة بكامل زينتك } \\
& \text { ليأخذك القشتال إلى السّكين } \\
& \text { هنا المدن الضيّائعة على مدّ الخريطة } \\
& \text { فهل سيجيء الثّاعر بعد قرون أخرى } \\
& \text { ليرى في قرطبة القدس ؟(طه، 10 أب) } \\
& \text { نعم عاد القشتال بقناع آخر: }
\end{aligned}
$$

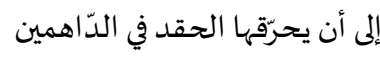

$$
\begin{aligned}
& \text { سلاما، إذا، للتماثيل والعنب الذّهبي } \\
& \text { على باب إقباء في الأوّلّين } \\
& \text { وفي الآخرين }
\end{aligned}
$$

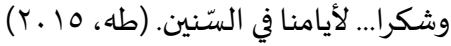

أمّا قصيدة " للقدس وجها آخر"، فقد بدت فها القدس بوجها مشرق جديد، حيث الحياة النشطة فهها، ويستشرف الثّاعر

المستقبل الذي يرنو إليه مع القدس، وهو عودة المآذن لصوتها النّقي:

$$
\text { للقدس وجها آخر }
$$

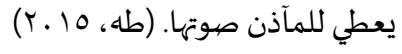

وهكذا يريدها كما يصبو لها الكلّ الفلسطيني، يتعاضد فيها محمّّد والمسيح، ويعيش النّاس بأمن وأمان دون تمييز:

$$
\begin{aligned}
& \text { وقد أسلّم باليدين وبالعيون على النّبي المصطفى إنى }
\end{aligned}
$$

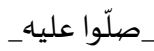

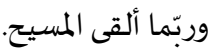

$$
\begin{aligned}
& \text { فعندها سيعيد لي ولدي } \\
& \text { ويبرئ صدره من صلية القنّاص } \\
& \text { أو ألقى الطَّهورة مريم العذراء }
\end{aligned}
$$

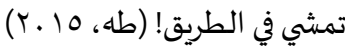

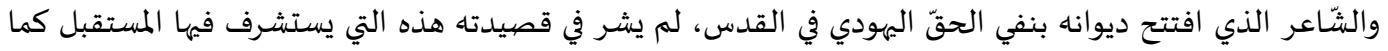

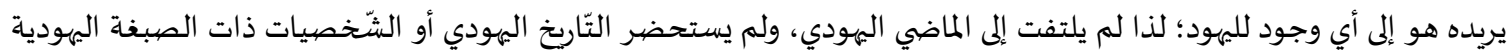

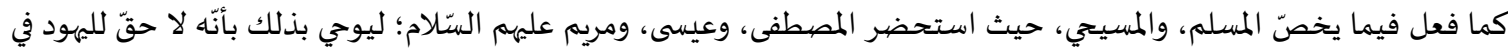
القدس كما يدّعون، بل لا يريدهم في القدس في مستقبلها الزّاهر.

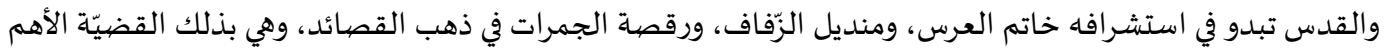

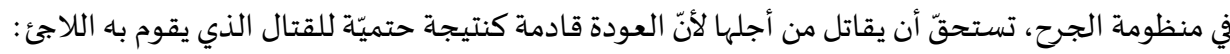
والقدس خاتم عرسنا الأبدي

منديل الزّفاف

ورقصة الجمرات في ذهب القلائد

ونشيدنا بمسيرة المفتاح

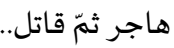

$$
\text { فهو عائد }
$$

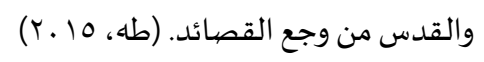

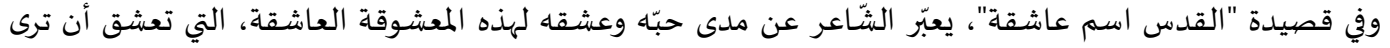

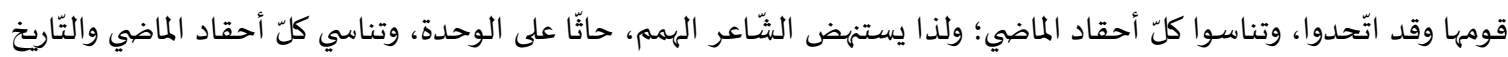

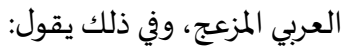




$$
\text { هذا كليب وهذي الأهل، كاد الخدّ يقتلني }
$$

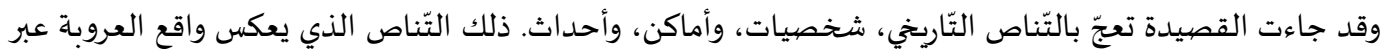
التّاريخ ذلك الضيدّ الذي لا يريده الشّّاعر، وكاد أن يقتله: داحس، والغبراء، والبسوس، وكليب، وجساس، وصفين، ... ( ينظر: طه،

ويرى الشّاعر أنّ قضيّة القدس مدعاة للوحدة، وللنّهوض بالأمة ورأب صدعها، وتوحيد كلمتها؛ لذا تبدو القدس جنّة

$$
\begin{aligned}
& \text { عاشقة ومعشوقة للجميع: الشامي والمصري والعراقي والحجاز ي والفاسي: }
\end{aligned}
$$

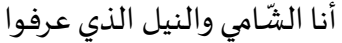

$$
\begin{aligned}
& \text { وابن العراق وكلّ الخلق من ناسي ... }
\end{aligned}
$$

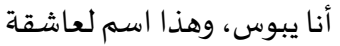

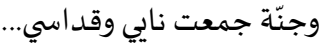

$$
\begin{aligned}
& \text { فتحت بابي على العشاق فاجتمعوا }
\end{aligned}
$$

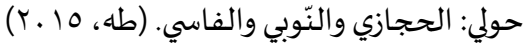

ويستحضر الشّاعر في دعوته أشقاءه للوحدة (يبوس) الاسم المرتبط بعراقة القدس وعروبتها، إذ إنّ هذا الاسم مدعاة الأنداة

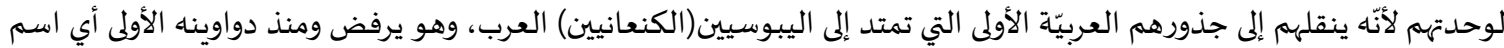

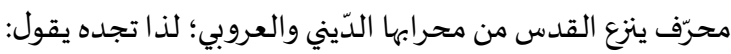

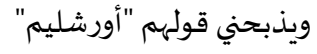

كأنّ يبوس خرافات أسفارنا الزَائفة

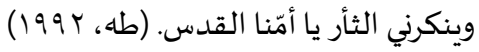

ولأجل هذا العشق لمعشوقته القدس التي تعشق الكلّ، يعزّ عليه أن تبقى أسيرة باكية:

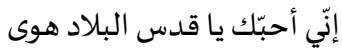

يفوق دفقة أضلاعي وإحساسي

يعزّ يا قدس أن تبكي على كتفي

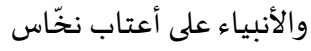

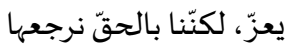

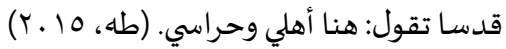

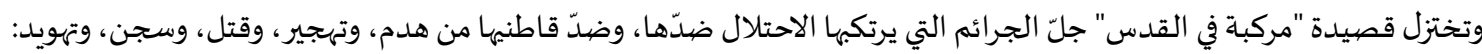
سلاما لكلّ البيوت التي أغلقوها

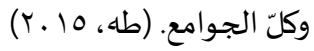

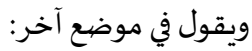

$$
\begin{aligned}
& \text { والعدسات تعيد المشاهد } \\
& \text { خمسين مفردة للجنائز } \\
& \text { والقتل } \\
& \text { والحرق } \\
& \text { والقلع } \\
& \text { والهدم } \\
& \text { والدّهم } \\
& \text { والستّن }
\end{aligned}
$$

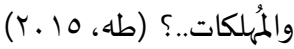


إذن كيف الخلاص؟ في لفتة ذكية تنقلنا عبر التّاريخ إلى مدينة "سرّ من رأى" التي بناها المعتصهم، يدرك المتلقي إيحائية

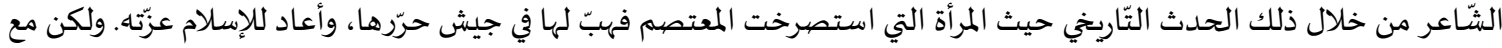

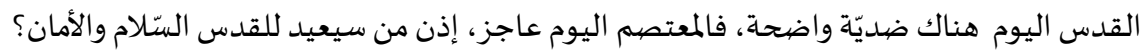
إنّها تلك المرأة التي استصرخت، المقدسيّة المرابطة الشّامخة:

$$
\begin{aligned}
& \text { وسرّ التي رآها هباء! } \\
& \text { ويعلم أنّ التي صرخت سوف الماءئ } \\
& \text { تحمي المآذن والسيّور } \\
& \text { والنّاس والباب والأنبياء } \\
& \text { ويعلم أنّ التي صرخت وحدابل والياء. } \\
& \text { من يعيد البراق.. ليسري حرّا } \\
& \text { إلى إيلياء } \\
& \text { سلاما إلى القدس، } \\
& \text { غصنا وطيرا، } \\
& \text { ودارا وقوسا، } \\
& \text { وشرفة ورد لعصفورة النّار }
\end{aligned}
$$

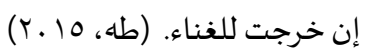

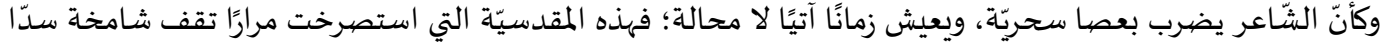

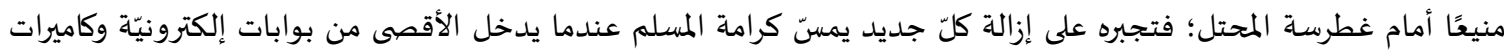

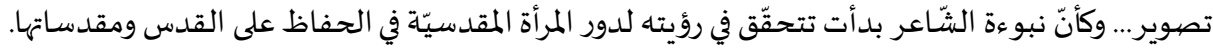

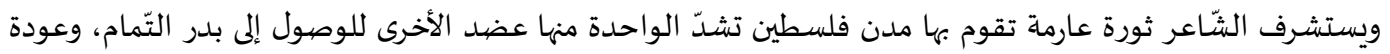

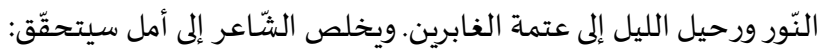

$$
\text { تكتب اليوم ما سدس }
$$

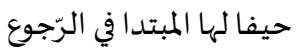

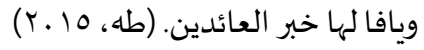

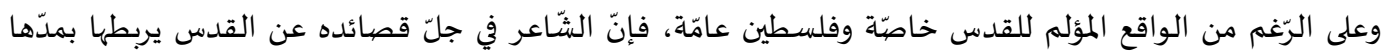

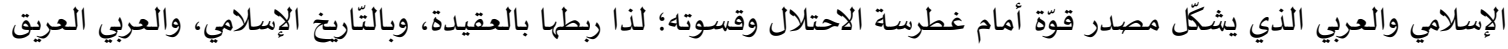

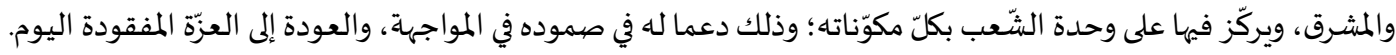

$$
\text { ثانيًا: بين اللجوء والنّزوح وأمل العودة }
$$

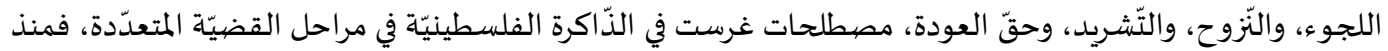

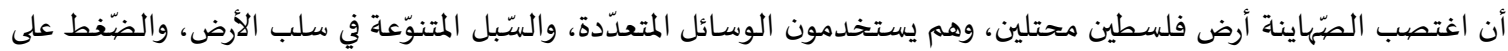

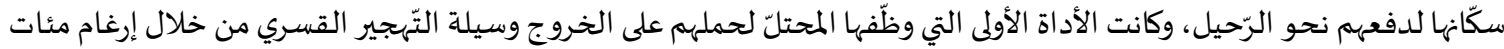

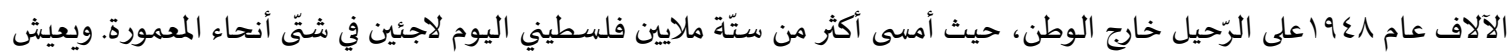

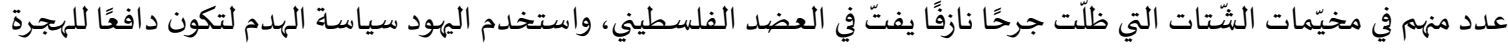

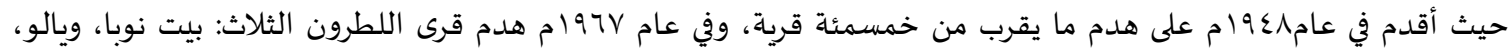

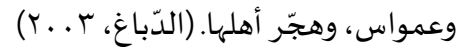

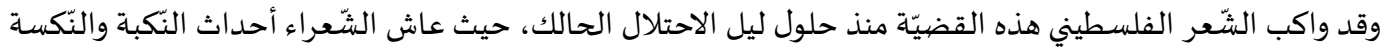

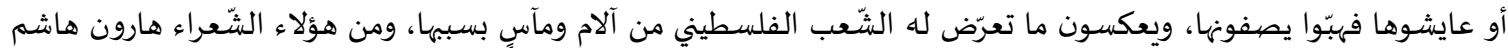

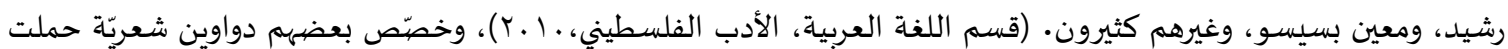


مصطلحات اللجوء والتّشريد كديوان "المشرّد" للكرمي، و"طائر الوحدات" لأحمد دحبور، فهذا عبد الكريم الكرمي مثلا يقول في

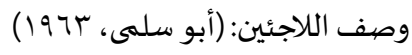
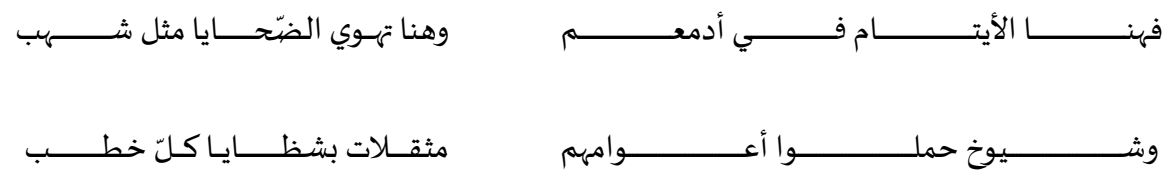

إنّهمه أهـــلي _على الدّهر_وصـــــبي

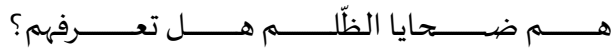

وقد شغلت هذه القضيّة المتوكل طه في ديوان "مملكة اليمام"، إذ إنّ الثّاعر يعزف أنغام الحزن والألم لكنّه يبدو

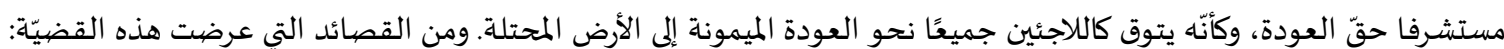

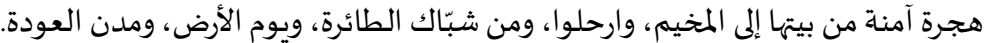

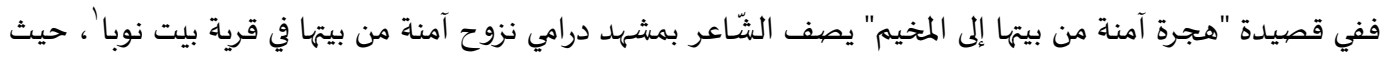

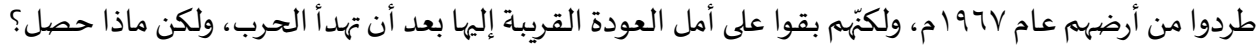
وعادوا ولكن إلى صفقات التّّجارة بالثُّهداء إنهاء

وبالوهم يرسم خارطة من جديد

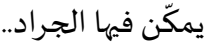

ويعطي لمن يسرقون الدّماء منازل في الرّبح فوق العباد عادوا ولكن إلى غيبة سوف تمبـد حتى نعيد الحروف إلى لغة الأرض إلى

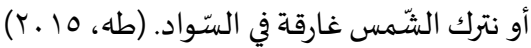
ويرسم الشّاعر في هذا المشهد صورة مؤلمة لأمنة التي غادرت قريتها محمّلة بالأحزان والآلام:

$$
\begin{aligned}
& \text { ومن بيت نوبا عشاء } \\
& \text { سيمشي الأب والأم بالدّمع } \\
& \text { والصبّبية الغامضيون إلى جها في الظّلام ... } \\
& \text { والعدا يرقبون الجماعات في سيرها } \\
& \text { نحو خيمتهم في القتام } \\
& \text { وآمنة وحدها } \\
& \text { مع عوائلها في الطّريق } \\
& \text { ولم تعرف الخوف إلا هنا... } \\
& \text { ولكنّا الآن في مبهم الوقت التحت } \\
& \text { قد كبرت ألف عام. (طه، } 10 \text {. r) }
\end{aligned}
$$

ثمّ يصف الشّاعر العبور نحو الشّرق عبر نهر الأردن، وهو عبور معاكس ومضياد لعبور العدوّ إلى البلاد المعروف تاريخيّا، وفي هذا

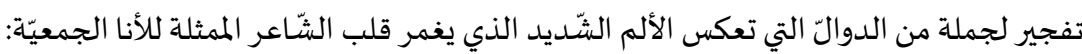

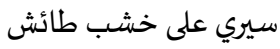

واقفزي فوق موجاته الرّاقصيات

أو جنّحي فوق صفحته كالحمام

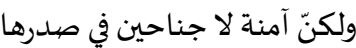

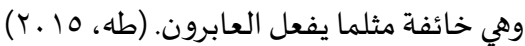

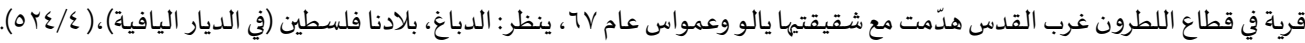


ومع أنّ مشهد الرحيل جسديًا ينتهي في عمون (الاسم القديم لعمان) دلالة على الأصالة والحضارة؛ إلا أنّ في هذا المكان يبدأ

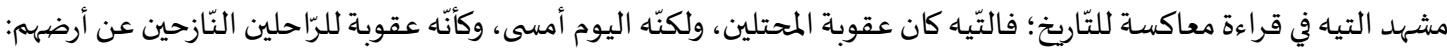

وربّة عمّون تفتح أزرارها

وردة للخيام

هنا ابتدأ التّيه قبل العواصف

أو قبل أن يشهق اللوز

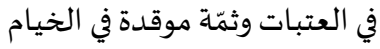

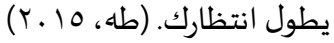

والشّّاعر لا يريد لفترة التّيّه أن تطول كثيرًا؛ لذا يبدأ الحلم بالعودة للدّيار من المكان الذي بَدأ فيها التّيّه، إذ يقول:

هنا ابتدأ الحلم في يقظة النّازحين

وآمنة في المجاز تعود

إلى بيت نوبا وعمواس

حتى تراها المجرات

تائهة

في كوابيس تابه

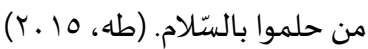

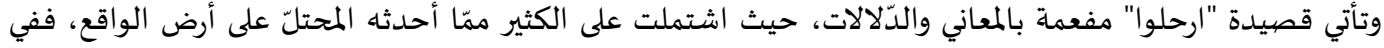

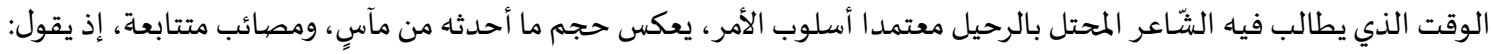

فما الذي تريده يا صاحب الدبّابة المجنزرة؟

وقد سرقت خبزنا وماءنا وعمرنا

ووردة المواقد المعطرة؟

فلترحلوا جميعكم من الجهات كلها. (طه، 10 .ب)

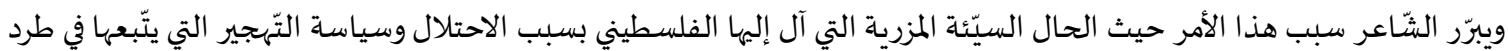

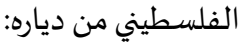

$$
\begin{aligned}
& \text { لالأنتا المنفيّ والحمّال والثَّحاد } \\
& \text { والتي تبيع لحمها..لأنّها } \\
& \text { ذبيحة الجزّار والصَغنار... } \\
& \text { لأنكم سحبتم الضَّفائر الشَّقراء } \\
& \text { والسّمراء للفراش، عنوة، } \\
& \text { ففاضت الدّماء من زهورها المختِّةرة. }
\end{aligned}
$$

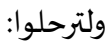

$$
\begin{aligned}
& \text { لأنكم قتلتم الكلام واليمام والشّجر } \\
& \text { لالأنّ حرقة اللجام كالشرر } \\
& \text { لأنّها السّجون تخنق القمر. } \\
& \text { لألنّا الفقير والأجير والغفير... } \\
& \text { فلترحلوا } \\
& \text { لألَّها الأرامل الضيّياع } \\
& \text { لأنكم سرقتم النّخاع } \\
& \text { لأنّنا الخراف في حظائر الضباع. (طه، } 10 \text {.ب) }
\end{aligned}
$$

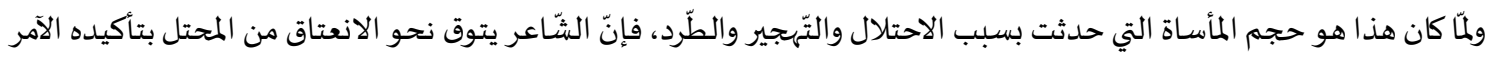

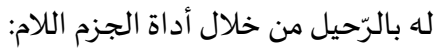




\section{فلترحلوا \\ ولترحلوا \\ ولترحلوا. (طه، 10 . ب)}

وقد وظّّف الههود وسائل عديدة لتّهجير النّاس وطردهم، ولعلّ الاستيلاء على الأرض ومصادرتها كانت من الطّرق الأكثرث

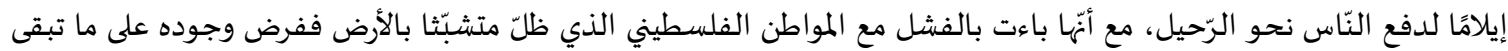

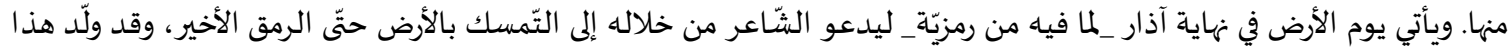

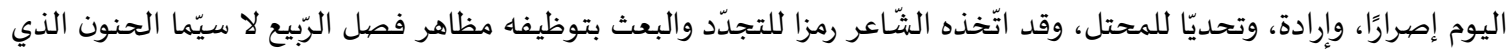

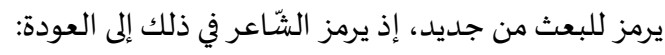
في آذار، يعود الحنون،

ويلد الحجر النّبوي جدائله المائية: وتكون تماثيل النثر على مدّ النّور... (طه، 10 ـ ب) ويستشرف الشّاعر التحرّر والتخلّص من الاحتلال بقوله:

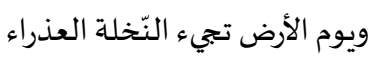
ويأتي الطُّفل ليرفض جلجية التحلة الصيّلبان ويكسر مطرقة الطُّغيان ويجعل درب الألم المرّ ل المّان

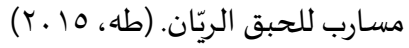
وحلم الأرض سيتحقّق في الزّمان والمكان على هذه الأرض:

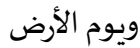

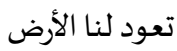

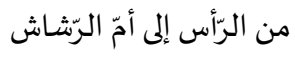

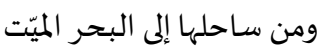

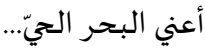
تعود لنا الأرض فلسطين الئن ولا شيء سواها

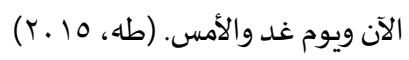
ويختتم عرس التّحرير ليعلن خاتمة الشّهداء بقوله:

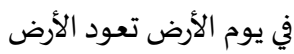

لتعلن خاتمة الشّهداء. (طه، 10 . ب)

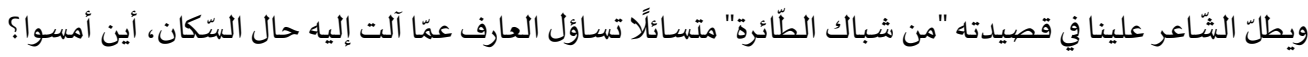
على غيمة من بياض شديد ترى ما تريد

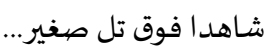

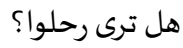

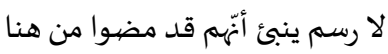

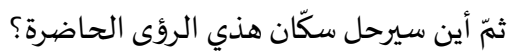

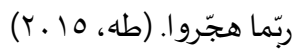
ويبدو الجواب في تناص مع النّص القرآني في أحداث يوم القيامة وآثارها، وكأنّ قيامة هؤلاء القوم قد حلّت في مشهد رهيب بقوله: من مشرق الشَّمس حتى المغارب قد حوّلته الغريبة 


$$
\begin{aligned}
& \text { ساحرة من بلاد العجائب } \\
& \text { في نظرة عابرة } \\
& \text { حوّلتها إلى ساحة مقفرة } \\
& \text { كالحة ناغرة } \\
& \text { لاهية سافرة } \\
& \text { ناعبة مدبرة } \\
& \text { اسمهها المقبرة... }
\end{aligned}
$$

وتصحو على غربة المجزرة

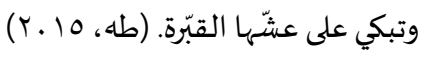

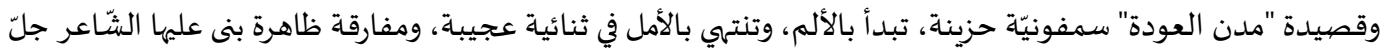

$$
\begin{aligned}
& \text { قصائده التي عرض فيها لمأساة اللجوء والنّزوح، حيث يقول: } \\
& \text { سأبدأ } \\
& \text { لكنّي قد بد أت قديما من الحزن }
\end{aligned}
$$

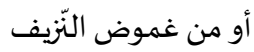

$$
\begin{aligned}
& \text { وقلت لهاجر }
\end{aligned}
$$

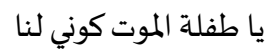

$$
\begin{aligned}
& \text { في الشّروق كما نشتهي عودة للبلاد } \\
& \text { وغنّيت للهاتفين } \\
& \text { فكيف سأبدأ ثانية } \\
& \text { والدّخان دم ماطر في الغروب المدابه }
\end{aligned}
$$

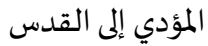

$$
\begin{aligned}
& \text { أو يجمع القرية التي حرّقوها }
\end{aligned}
$$

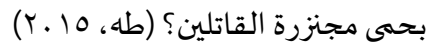

وتزخر القصيدة بمفردات مستوحاة من ذاكرة الرّحيل لازمت الفلسطيني أينما حلّ كاللجوء، والنّزوح، والشّهادة،

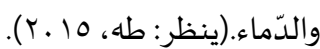

ولمّا كان الصّراع بين المحتل والفلسطيني على المكان، ظلّ له نكهة خاصيّة لدى الثّاعر الفلسطيني، فمنه ينطلق التّحرير، من كلّ مكان داخل الوطن:

$$
\text { حيا قدسا لها المبتدا في الرّجوع }
$$

يبدو من خلال القصائد التي تمّ عرضها، تلك التي تحدّثت عن اللجوء والنّزوح أنّ الثّاعر يبقي على بصيص الأمل بالعودة

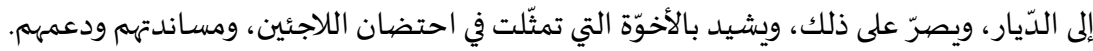

ثالثًا: عرس الشّهادة تجسيد للمأساة وبعث من جديد

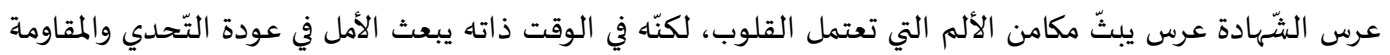
للمحتل وصولًا إلى التخلّص من الاحتلال، ذلك الحلم الذي ما زالت تحياه الأنا الشّاعرة الممثّلة للأنا الجمعيّة الفلسطينيّة.

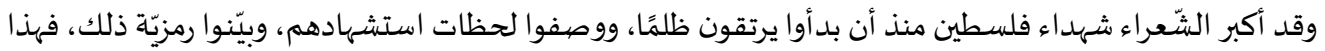
طوقان يصف بملحمة جميلة لحظات تسابق الشّهداء على حبل المشنقة في ثلاثيّة الشّهداء (الثلاثاء الحمراء): (طوقان، ـ 99 () 


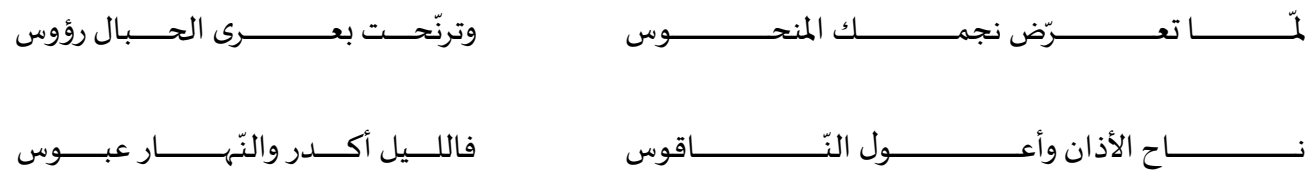

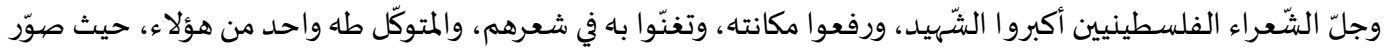

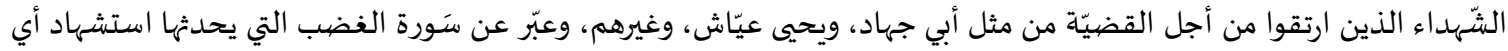

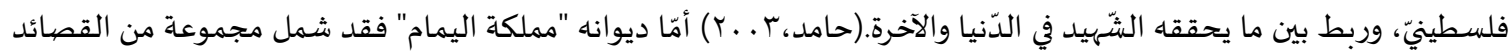

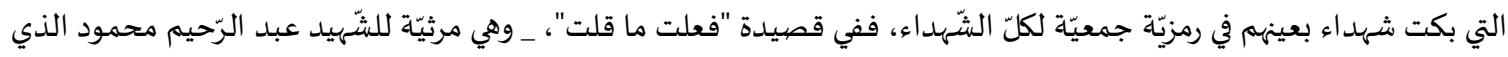

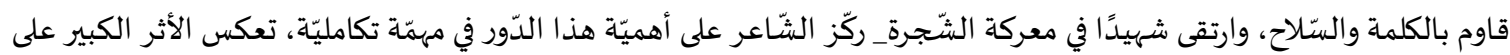

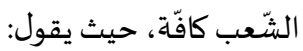

$$
\begin{aligned}
& \text { وقّعت بالدّم شعرا فاستجاب له } \\
& \text { شعب شهيد بريح المسك يلقاه } \\
& \text { فعلت ما قلت! هذا ما اجترحت لنا } \\
& \text { من معجزات، وذات الفعل حرفاه } \\
& \text { موت الشّهيد مجاز فالخلود له } \\
& \text { واللحد إن ضمّمها فالله أحياه } \\
& \text { ولو أتاح لنا المولى الصلاة إلى }
\end{aligned}
$$

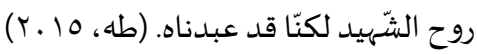

يظهر في النّص البعد الديني بشكل جليّ، فالشّهيد ميّت مجازا، وهو خالد حقيقية، وتظهر المفردات الإسلاميّّة التي تحمل

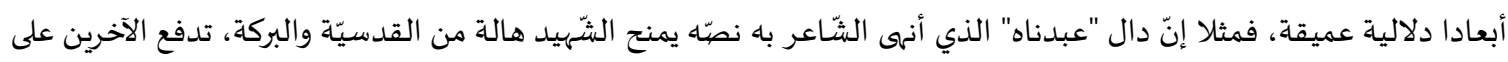

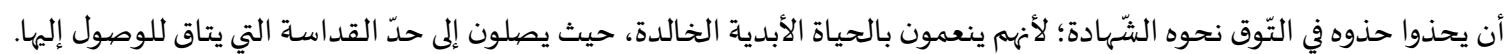

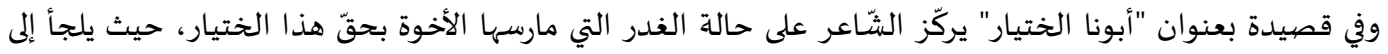

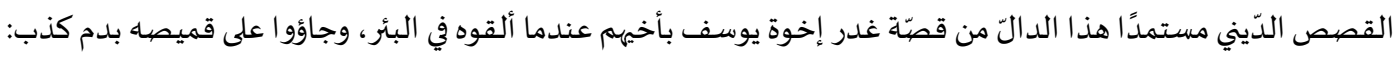

$$
\begin{aligned}
& \text { أبونا له ألف يوسف في الأرض إخرا يوسف } \\
& \text { قمصبانهم في رماح الأشقّاء }
\end{aligned}
$$

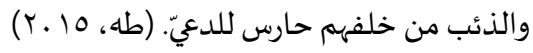

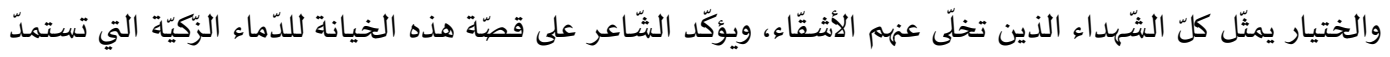

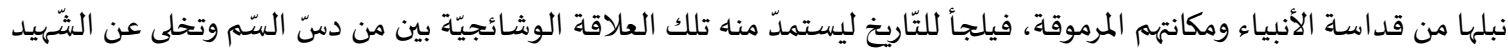

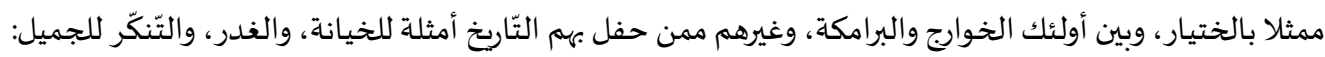
إنتما قد يعود الخوارج بيننا والبرامكة العنكبوت

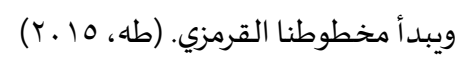

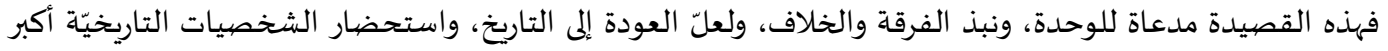

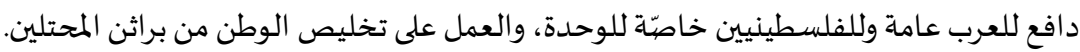

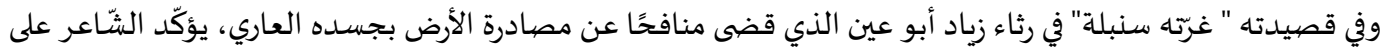

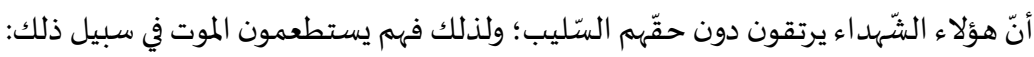

$$
\begin{aligned}
& \text { لن يتركوك تتمّم ما اجترح الثَّهداء } \\
& \text { وأخشى من العضّة النّادمة } \\
& \text { فليقتلوني، إذًا دون حقِّي، } \\
& \text { ولا عيش للأنفس الرّاغمة. (طه، 10 . T) }
\end{aligned}
$$


ويتذكّر الشّاعر ما عاناه الشّهيد من المحتل، وهو ديدن جلّ الشّهداء، حيث يتنقلون بين سجن، وجرح، وتعذيب، ليتوّج

ذلك كلّه بالشّهادة:

$$
\text { كم مرّة سوف يأخذك النّاي }
$$

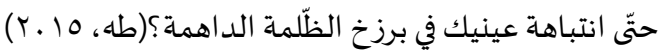

ويربط الشّاعر بين الشّهيد والأرض بكل أشيائها ومكوّناتها؛ لأنّ الشّهداء يرتقون من أجلها، ويختار من بين أشيائها تلك

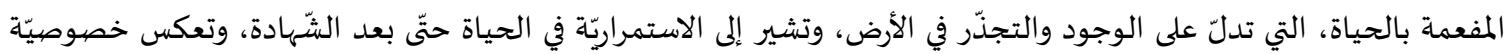
المكان ورمزيّتا:

$$
\begin{aligned}
& \text { تجلّيت يا صاحبي مثل زيتونة الحقل، }
\end{aligned}
$$

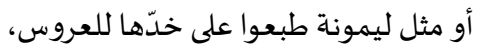

$$
\begin{aligned}
& \text { وأكملت زينتك، اليوم، فاخرج علينا }
\end{aligned}
$$

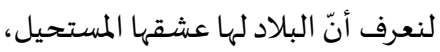

$$
\begin{aligned}
& \text { وأنّ لأعراسها الأخذة الحاسمة. (طه، } 10 \text { • ب) }
\end{aligned}
$$

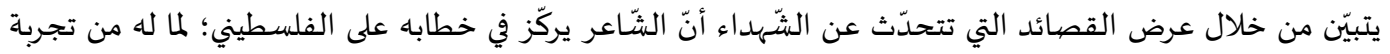
يوميّة في إدراك وقع الشّهادة وتداعياتها، فهو يعيشها واقعا يوميا، ويحسّ بآثارها عليه. ولكنّه في الوقت ذاته لا ينسى الإشارة للتّاريخ؛

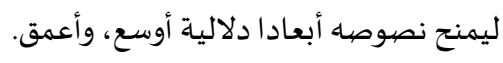

$$
\text { رابعًا: غزّة بين التّطهير العرقي والمقاومة }
$$

ارتكب المحتلّ الإسـرائيلي منذ أن حلّ على هذه الأرض الكثير من المجازر التي كانت نهجًا متّبعًا في محاولة لتهجير السّكان،

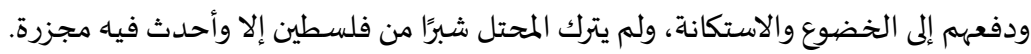

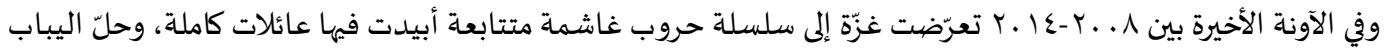

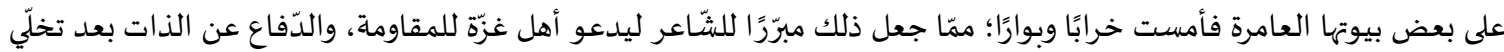
الكلّ عنهم:

$$
\text { ولم وقاوم بمن مسحوا من سجّل الحياة، }
$$

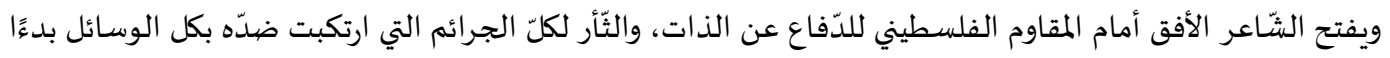

بالأدوات البسيطة التي فَرضت على المحتل واقعًا جديدًا يحسب فيه ألف حسـاب للصّّفير والكبير، والأدوات التي تطوّرت وأمست

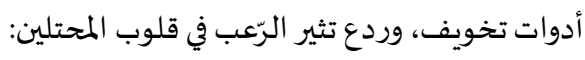

$$
\begin{aligned}
& \text { وقاوم بأغنية الأرض والمولوتوف وزخّ الحجارة } \\
& \text { قاوم بصياروخ فتح } \\
& \text { وصاروخ جيم } \\
& \text { وصاروخ قاف } \\
& \text { وما من سماح } \\
& \text { وما من شفاعة } \\
& \text { وقاوم فقد جاء وقت السّباع، } \\
& \text { وولّّ زمان قطيع الخراف. (طاء، } 10 \text {. ب) }
\end{aligned}
$$

وتبدو في هذا النّص تلك الدّعوة للوحدة الوطنيّة فيما يتعلق بموضوع المقاومة؛؛ ممّا يؤدي إلى استمراريّها، وشدّة فعاليتها،

$$
\text { وأثرها المرعب، إلى أن يتمّ عرس التحرّز والانعتاق من الاحتلال للأرض الفلسطينيّة كاملة: }
$$




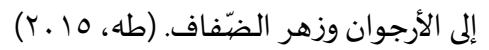

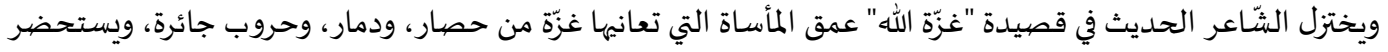
تلك المجازر التي حلّت بالفلسطينيّين في لفتة لاستمرار المسلسل الدّامي غير المتناهي، على اختلاف المّاف الزّمان والمكان، مستحضرًرًا مجازر تركت بصمات الكمد والأسى على مسيرة القضيّة الفلسطينيّة: سلام على ماء قانا وصبرا على ما تبعثر سطرا فسطراء قانا ومبرا على خيمة في عراء الطُّحين. سلام على داليات الصيّفيح

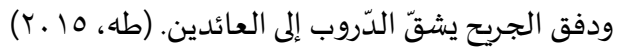

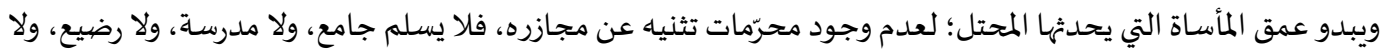
بيت صفيح يأوي لاجنًا مطرودًا من بلده قبل سنين: سلام على كلّ حيّ ودار

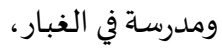

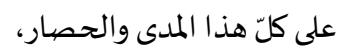
سلام على جامع هدّموه

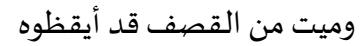
وسقف على أهله ردّموه

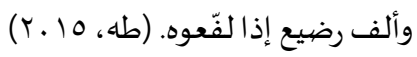
فلا الجامع بيت العبادة، ولا المدرسة بيت العلم بناجِ من جرائم المحتل.

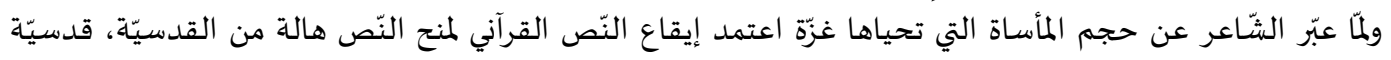

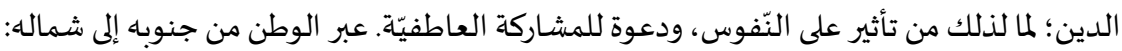
فإن قصفوا رفحا في المساء..

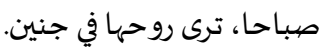

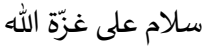
فيها الممات وفيها الحياة

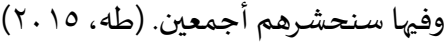

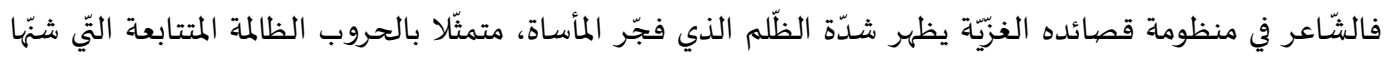

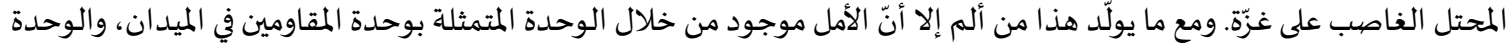

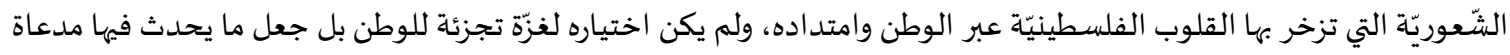

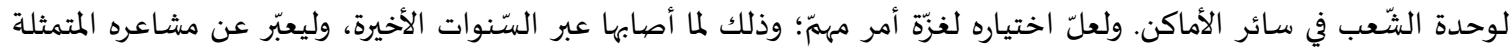

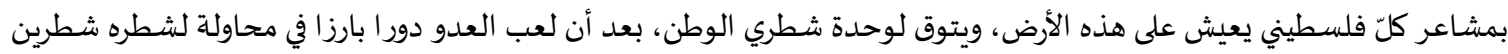

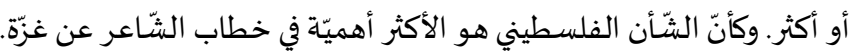

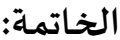

عرض البحث لتجلّيات الوطن في ديوان "مملكة اليمام"، حيث تتبّع الفضاء الموضوعي في الدّيوان، وما يجلّيه من تقنيات أسلوبية

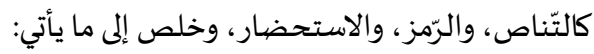

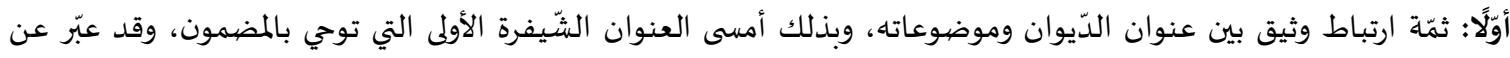
مدلولات الدّيوان باختصهار.

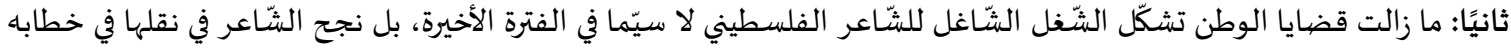

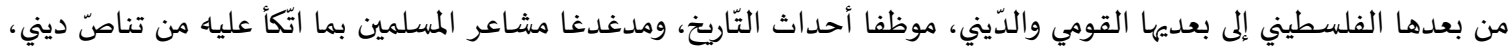
واستحضار للشَّخصيات التّاريخيّة. 
ثالثًا: شكّلت قضايا القدس، واللجوء، والثّهيد، وغزّة محاور مهمّة في قصائد الدّيوان وهي بذلك تشكّل مملكة اليمام عنوان الديوان.

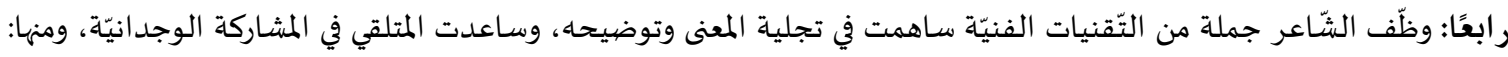

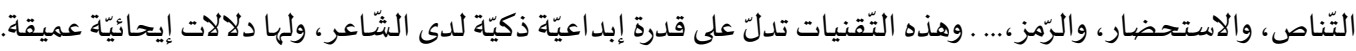

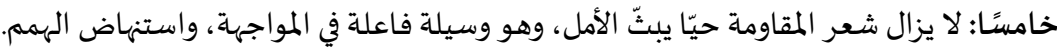

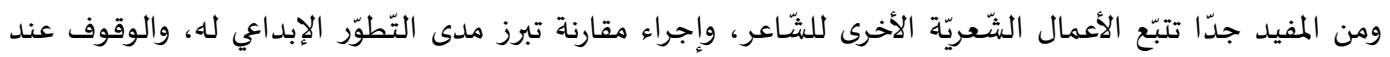

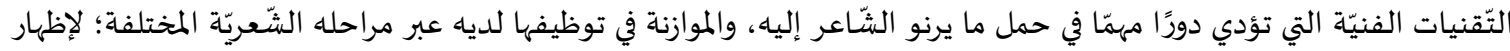
تطوّر الخطاب الشَّعري لدى الشّّاعر.

المراجع:

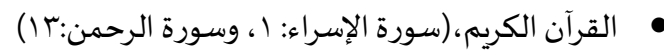

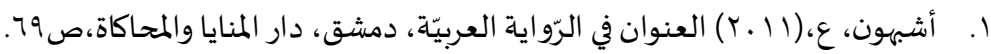

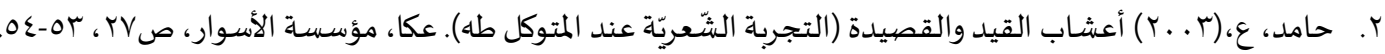

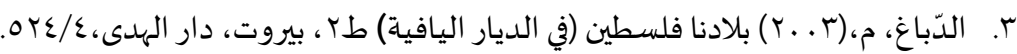

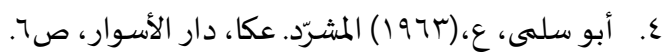

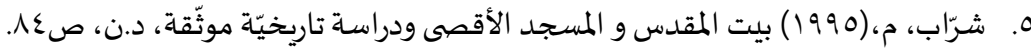

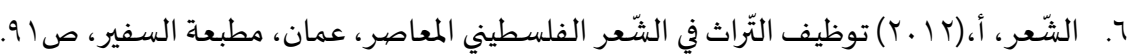

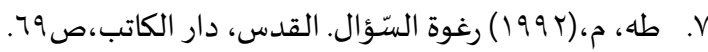

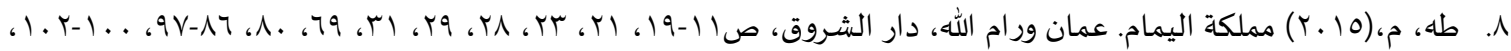

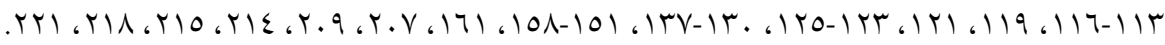

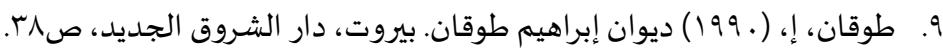

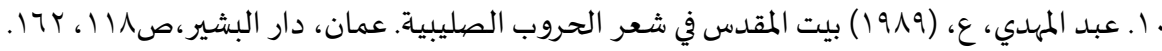

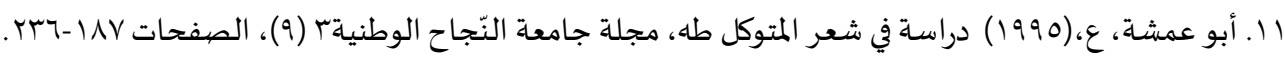

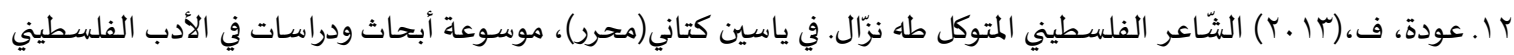
(Y)

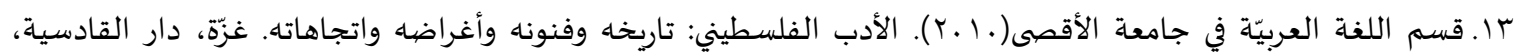

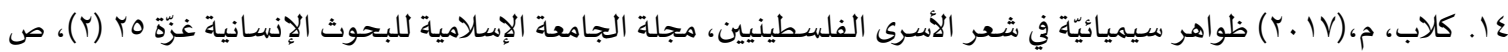

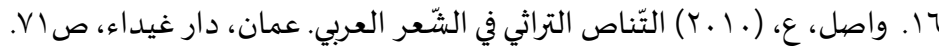




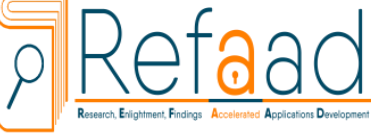

رفاد للدراسـات والأبحاث

www.refaad.com
المجلة الدولية للدراسات اللغوبة والأدبية العربية

e-ISSN 2663-5860, p-ISSN 2663-5852

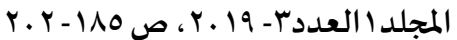

https://doi.org/DOI:10.31559/JALLS2019.1.3.3

\title{
Aspects of Homeland in Dewan Mamlaket Alymam for Al- Motawakel Taha
}

\author{
Khamees Ahmad Rayyan \\ Ministry Of Education- Ramallah- Palestine \\ Birzeit University- Palestine \\ khrayyan69@gmail.com
}

\begin{abstract}
This research aims at showing up the issues of homeland which the poet expressed in his poetry (his Dewan) for making sure that homeland is still the main concern in the Palestinian poetic speech at a time of changes taking place all around the world, affecting the Palestinian issue.

The research is based on taking the poetic text and then analyzing it, depending on the descriptive approach which reads the texts and then analyze them. The study employs the analytical approach and its techniques such as intertextual, employment of historical figures and semiotics in the connection between the title and the subjects. The poet included the Palestinian personality through highlighting different issues of Palestinian homeland: Al-Quds (Jerusalem), Refuge (Diaspora), Martyrdom and Gaza which has been exposed to destructive wars during the past few years; in which it created a painful bleeding wound in the body of Palestinian homeland.

The study concluded that there is a strong connection between the title, which is regarded as the code, and the Dewan's subjects related to the Palestinian homeland, and the idea that the homeland is still the most dominant in the Palestinian poetic speech. Moreover, the poet was able to employ stylistic techniques that exploded implications that the poet wanted to convey in his poems to his readers to make them take part in emotionally.
\end{abstract}

Keywords: aspects of homeland; Al-quds (Jerusalem); refuge (Diaspora); Martyrdom; intertextuality

\section{References:}

- A Alqrận Ạlkrym,(Swrẗ ẠlạSrạ’: 1, Wswrt Ạlrḥmn:13)

[1] 'bd Ạlmhdy.', Byt Ạlmqds Fy Sḥ'r Ạlḥrwb Ạlṣlybyh, 'mạn, Dạr Ạlbshnyr, (1989), pp.118, 162.

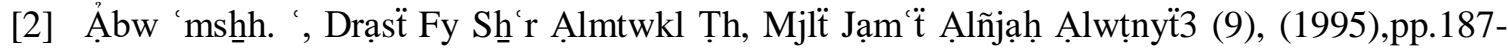
236.

[3] 'wdh. F, Ạlsh̆ạa'r Ạlflsțyny Ạlmtwkl Ṭh Nz̃ạl. Fy Yạsyn Ktạny(Mḥrr), Mwsw ‘̈ Ạ̉bhạath Wdrạsạt Fy Ạlạ̉db Ạlflsțyny (427-457), Bạqï Ạlghhrbyh: Ạ̉kạdymyh Ạlqạsmy, (2013), pp.427-457.

[4] Ảshbhbwn. ', Ạl'nwạn Fy Ạlr̃wạyh Ạl'rbỹh, Dmsḥq, Dạr Ạlmnạyạ Wạlmḥạkạh, pp. 69, (2011) 
[5] Ạld̃ạagh. M, Blạdnạ Flsțyn (Fy Ạldyạr Ạlyạfyh) Ṭ2, Byrwt, Dạr Ạlhdỵ, (2003) 4/524.

[6] Ḥạmd. ', Ả 'shạab Ạlqyd Wạlqșydh (Ạltjrbh Ạlsḥ 'rỹh 'nd Ạlmtwkl Ṭh). 'kạ, Mw̉ssẗ Ạlạ̉swạr, (2003), Ș27, 53-54.

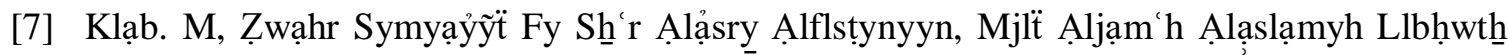
Ạlạnsạnyh Ghzz̃a 25 (2), (2017), pp. 1-15.

[8] Mftạh. M, Ạstrạtyjy̆t Ạltnạ̣s, Byrwt Wạldạr Ạlbyḍạ’, Ạlmrkz Ạlthaqafy Ạl'rby, (1985), pp. 263.

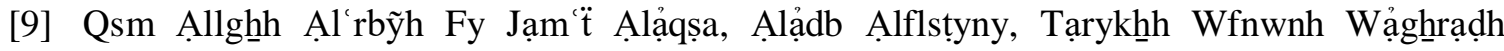
Wạtjạhạth. Ghzzãa, Dạr Ạlqạdsyh, (2010), pp.102.

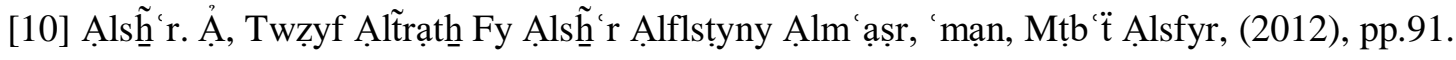

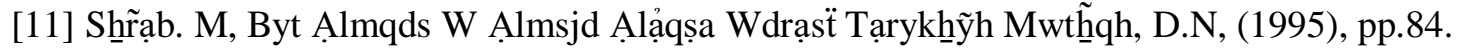

[12] Ạ̉bw Slma. ', Ạlmsḥ̂rd. 'kạ, Dạr Ạlạ̉swạr, (1963), pp.6.

[13] Ṭaha. M, Mmlkë Ạlymạm. 'mạn Wrạm Ạllh, Dạr Ạlsḥrwq, (2015), pp. 11-19, 21, 23, 28, $29,31,69,80,86-97,100-102,113-116,119,121,123-125,130-137,151-158,161,207$, $209,214,215,218,221$.

[14] Ṭaha. M, Rghwwë Ạls̃w̉ạl. Ạlqds, Dạr Ạlkạtb, (1992), pp. 69.

[15] Țwqạn. A̦, Dywạn A̦ßBạhym Țwqạn. Byrwt, Dạr Ạlsḥrwq Ạljdyd, (1990), pp.38.

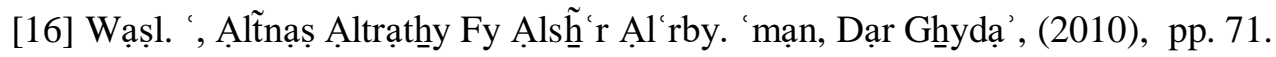

